University of Nebraska - Lincoln

DigitalCommons@University of Nebraska - Lincoln

\title{
Maintenance of a narrow host range by Oxyops vitiosa; a biological control agent of Melaleuca quinquenervia
}

\author{
G. S. Wheeler \\ University of Florida
}

Follow this and additional works at: https://digitalcommons.unl.edu/usdaarsfacpub

Part of the Agricultural Science Commons

Wheeler, G. S., "Maintenance of a narrow host range by Oxyops vitiosa; a biological control agent of Melaleuca quinquenervia" (2005). Publications from USDA-ARS / UNL Faculty. 388.

https://digitalcommons.unl.edu/usdaarsfacpub/388

This Article is brought to you for free and open access by the U.S. Department of Agriculture: Agricultural Research Service, Lincoln, Nebraska at DigitalCommons@University of Nebraska - Lincoln. It has been accepted for inclusion in Publications from USDA-ARS / UNL Faculty by an authorized administrator of DigitalCommons@University of Nebraska - Lincoln. 


\title{
Maintenance of a narrow host range by Oxyops vitiosa; a biological control agent of Melaleuca quinquenervia
}

\author{
G.S. Wheeler* \\ USDA/ARS Invasive Plant Research Lab and University of Florida, 3205 College Avenue, \\ Ft Lauderdale, FL 33314 USA
}

Received 23 January 2004; accepted 13 October 2004

\begin{abstract}
Host range expansion in insect herbivores is often thought to be mediated by several factors, principal among them are secondary plant metabolites. In weed biological control, the host range of a prospective agent is one of the most important considerations in its implementation. Extensive host testing tests seek to determine the behavioral acceptance and nutritional value of different test plant species to the potential agent. A list of test plants is compiled that comprises species that are close taxonomic relatives of the target weed plus other species of economic or ecologic importance. The host testing of the Melaleuca quinquenervia biological control agent Oxyops vitiosa indicated that larvae would accept and complete development on the Australian target weed M. quinquenervia, two Australian ornamental species, Callistemon citrina, Callistemon viminalis (all Myrtaceae). However, the larvae did not complete development when fed a North American species Myrica cerifera (Myricaceae). The study reported here confirms these results and examines the nutritional and performance differences in $O$. vitiosa larvae fed leaves of these species. The leaf quality factors, percent moisture, percent nitrogen, toughness, and terpenoid content were related to larval survival, performance and digestive indices. The results indicate that plant quality among the Myrtaceae species was generally similar and correspondingly larval survival, performance and digestive indices differed little when larvae were fed leaves of these species. However,
\end{abstract}

\footnotetext{
* Tel.: + 1954475 0541x108; fax: + 19544769169 .

E-mail address: wheelerg@saa.ars.usda.gov
}

0305-1978/\$ - see front matter Published by Elsevier Ltd. doi:10.1016/j.bse.2004.10.010 
significant differences occurred in the plant quality of the North American $M$. cerifera compared with the Australian species which had leaves with the lowest percent moisture, lowest leaf toughness, highest percent nitrogen. This species, however, is not a physiological host as none of the neonates survived to pupate. When third instars were switched to $M$. cerifera from their normal host $M$. quinquenervia reductions were found in survival, biomass gain, digestive efficiency, and conversion of digested food to insect biomass. The marginal acceptance of this North American native plant in laboratory bioassays appears related to the terpenoid chemistry that has similarities to the taxonomically unrelated host M. quinquenervia. However, the high larval mortality corresponds to several novel terpenoids that are not present in the host. For weed biological control host testing these results indicate that $M$. cerifera is a poor host for $O$. vitiosa. Additionally, future test plant lists should include plants with secondary metabolites similar to the target weed as these compounds may constitute behavioral cues that are relevant to these specialized herbivores.

Published by Elsevier Ltd.

Keywords: Host plant range; Nutritional quality; Weed biological control; Nitrogen; Terpenoids

\section{Introduction}

Understanding the secondary plant metabolites involved in selection and utilization of hosts and the toxicity of non-hosts can reveal the mechanisms that maintain specificity in specialist herbivores. The insect herbivores required for weed biological control use a narrow range of host plants for adult feeding, oviposition, and larval growth and development. This specialization may be imposed by several factors either from the plant (e.g., secondary metabolites; Stadler, 1992) or from outside the plant (e.g., natural enemies; Bernays and Graham, 1988). Factors produced by the plant include secondary plant metabolites that may function as deterrents against non-adapted herbivore species or as attractants and/or recognition factors for adapted species (Schoonhoven et al., 1998). Foliar mono- and sesquiterpenoids are known to function as both chemical defenses against herbivores and as feeding stimulants (Gershenzon and Croteau, 1991; Langenheim, 1994). Many terpenoids are restricted in their distribution in plants (Gershenzon and Croteau, 1991), or unique species-specific chemical profiles occur, and thus may provide distinctive host plant cues that are used by herbivores searching for a suitable host (Wibe et al., 1997).

The initial steps of weed biological control programs involve the determination of the host range of a prospective agent prior to consideration for release. Accurately predicting the host range of a potential agent is fundamental to this process. This may be conducted first in the country of origin in open field testing (Briese et al., 2002) and later under controlled environmental conditions in quarantine (Zwölfer and Harris, 1971; McFadyen, 1998). Initially a plant test list is established composed of species that are taxonomically related to the weed and species of economic and ecologic importance from the area where the weed is a problem (Wapshere, 1974). 
This centrifugal/phylogenetic testing procedure involves "testing plants of increasingly distant relationship to the host until the host is circumscribed" (Wapshere, 1974) and is based upon the assumption that host shifts occur to plants of similar taxa (Ehrlich and Raven, 1964; Mitter and Farrell, 1991). As useful as this process is, it potentially overlooks unrelated plant taxa that share similar secondary plant metabolites. Moreover, the distribution of secondary metabolites in plants only inconsistently follows taxonomic designations (Wink, 2003). Recent evidence indicates that chemical similarity may be a better predictor of host use than are phylogenetic relationships (Becerra, 1997; Wahlberg, 2001). Although little evidence may exist from weed biological control projects (Schaffner, 2001), species with secondary metabolites similar to the target weed should be included in the test list as they may contain the behavioral cues used by these specialized herbivore species to locate hosts and initiate feeding.

The Australian weevil Oxyops vitiosa, Pascoe (Coleoptera: Curculionidae) was introduced in south Florida, USA in 1997 for the biological control of the invasive weed Melaleuca quinquenervia (Cav.) S. T. Blake (Myrtaceae) (Center et al., 2000). This weevil species has since been established throughout the infested area of Florida. The larvae feed on the young leaves and have a characteristic odor that resembles that of the foliage of their host tree (Wheeler et al., 2003). Australian field collections of $O$. vitiosa indicated that this species restricts its feeding to its primary host $M$. quinquenervia and a few close relatives (Balciunas et al., 1994). In no-choice laboratory trials feeding and oviposition by this species occurred on other members of the Myrtaceae but the larvae only completed development on M. quinquenervia (Balciunas et al., 1994). Quarantine host testing of $O$. vitiosa suggested that suitable hosts included several species of Australian ornamental myrtaceous plants (Balciunas and Buckingham, 1996). Considering their taxonomic proximity to the target weed, feeding on these close relatives was not surprising. These included species of Callistemon, a genus whose members are closely related to Melaleuca (Byrnes, 1986; Craven, 1999). Representatives of this genus that were tested include Callistemon citrina (Curtis) Skeels and Callistemon viminalis (Sol. Ex Gaertner.) $\mathrm{G}$ Don ex Loundon. The taxonomy of these genera is still being revised, and although these were identified as Melaleuca spp. (Craven, unpublished data; Australian National Herbarium, Canberra), the more traditional names are included here, as this revision has yet to be published. More surprising however, while no neonates could survive, a few of the third instars of $O$. vitiosa previously fed $M$. quinquenervia leaves could feed and complete development on leaves of the unrelated wax myrtle Myrica cerifera L. (Myricaceae). Confirmation of these results is essential to continue promoting this insect as a biological control agent of $M$. quinquenervia. Furthermore, understanding the secondary metabolites that are common among the weed and test plants and the potential agent's response to these species will assist in our understanding of agent specificity and allow practitioners to better predict the host range of future agents.

The objectives of this study were to determine the larval survival and performance (consumption, growth, development, food digestibility and feeding efficiency) of $O$. vitiosa when fed leaves of these species and the target weed. In addition to 
terpenoid content, several plant quality factors were examined that were found previously (Wheeler, 2001) to influence $O$. vitiosa performance, namely leaf toughness, water content, and percent nitrogen. This information will determine the safety of this agent for continued field release and examine the mechanisms of host utilization by this specialist herbivore.

\section{Methods and materials}

\subsection{Plants}

Plants of the weed $M$. quinquenervia were obtained from seeds collected in south Florida and plants of the ornamental species $M$. cerifera, C. citrina, and $C$. viminalis were purchased as seedlings from commercial ornamental growers. All plants were transplanted into larger pots (11.4 1) and fertilized with $90 \mathrm{~g} /$ pot Osmocote Plus 15-912, N-P-K (Scotts-Sierra Horticultural Products, Marysville, OH) in a slow-release 'southern' formulation (Wheeler, 2003). Plants were grown in tanks that received rainwater and irrigation three times/week for approximately 6 months. Three times weekly, leaves were clipped from trees and brought back to the laboratory. As $O$. vitiosa is a known flush-feeder (Wheeler, 2001), only the silky terminal $10 \mathrm{~cm}$ tip leaves of each tree species were collected and either used for plant quality analysis or fed to larvae.

\subsection{Plant quality}

Several leaf quality factors that are relevant to herbivore nutrition were investigated including leaf toughness, percent moisture (for determination of nutrient dilution), nitrogen content, and terpenoid constituents. Leaves were tested for toughness using a modified gram gauge (Wheeler, 2001) which estimates the pressure required to puncture leaf tissues. Leaf toughness was measured on leaves 1-10 counting from the tip leaves toward the branch base. Replicates consisted of 20 leaves of each position. Leaf percent moisture $(n=65)$ was determined gravimetrically by weighing each leaf (positions 1-10) fresh and after drying $\left(60{ }^{\circ} \mathrm{C}\right)$ for $48 \mathrm{~h}$. Percent nitrogen $(n=3)$ was determined individually for leaves in positions 1-10 with a Kjeldahl method on a dry mass basis as previously described (Wheeler, 2001). These dry mass nitrogen estimates were converted to fresh mass nitrogen by multiplying the percent nitrogen (dry mass) by the proportion of leaf dry mass.

\subsection{Terpenoid analysis}

Flush leaves were clipped from young trees of $M$. quinquenervia $(n=10)$, $C$. citrina $(n=6), C$. viminalis $(n=6)$, and $M$. cerifera $(n=5)$ and brought to the laboratory where they were frozen $\left(-10{ }^{\circ} \mathrm{C}\right)$ as described previously (Wheeler et al., 
2003). The leaf components were extracted by a modified microwave technique (Wheeler et al., 2003).

\subsection{Chemicals}

Standards were purchased from commercial sources, or donated (viridiflorol, and 2,4-dihydroxy-6-methoxytoluene) by I. A. Southwell (NSW Agriculture, Wollongbar Agricultural Institute, NSW, Australia) and were of the highest purity available. The standards included the primary compounds reported by Brophy et al. (1989) and Wheeler et al. (2003).

\subsection{Gas chromatography}

Samples were analyzed with an Agilent (Hewlett-Packard) model 6890 gas chromatograph. Data collection, storage, and analysis were conducted with the Agilent ChemStation (Wilmington, DE) data system. Helium at a linear flow rate of $37 \mathrm{~cm} / \mathrm{s}$ was used as a carrier gas. All samples were analyzed on a fused silica capillary column (DB-17MS Agilent; $30 \mathrm{~m} \times 0.32 \mathrm{~mm}$ i.d., 0.25 micron thick film). Injector temperature was $250{ }^{\circ} \mathrm{C}$ and FID temperature was $250{ }^{\circ} \mathrm{C}$. The oven temperature was held at $50{ }^{\circ} \mathrm{C}$ for $2 \mathrm{~min}$, then increased at $8{ }^{\circ} \mathrm{C} / \mathrm{min}$ to $250{ }^{\circ} \mathrm{C}$ where it was held for $10 \mathrm{~min}$.

Compound identities were confirmed by GC-MS using an Agilent 6890 instrument fitted with either an HP-5MS (Agilent, $30 \mathrm{~m} \times 0.25 \mathrm{~mm}, 0.25$ micron film thickness) or a DB-17MS (J\&W Scientific, $30 \mathrm{~m} \times 0.32 \mathrm{~mm}, 0.25$ micron thick film) FSOT column with helium at 36 or $42 \mathrm{~cm} / \mathrm{s}$ (HP-5MS and DB-17MS, respectively) as a carrier gas, injector port (split 1:50) at $250{ }^{\circ} \mathrm{C}$, mass selective detector (HP 5973) at $250{ }^{\circ} \mathrm{C}$ (source) and $150{ }^{\circ} \mathrm{C}$ (quad) with transfer line $280{ }^{\circ} \mathrm{C}$ and ion source filament voltage of $70 \mathrm{eV}$. Component identification was made on the basis of mass spectral fragmentation, retention index with $n$-paraffins, comparison with authentic constituents when available, and mass spectral and retention matching with commercial libraries (NIST, Wiley, and Adams).

\subsection{Larval survival, growth, and development}

Eggs of $O$. vitiosa were obtained from wild adults collected on $M$. quinquenervia in Ft Lauderdale, FL. Larval performance was determined when fed leaves of the different plant species using both neonates $(n=20)$ and third instars $(n=20)$ previously fed $M$. quinquenervia leaves. All $O$. vitiosa larvae were reared through to pupation individually in plastic petri dishes $(15 \times 2 \mathrm{~cm})$ lined with moistened filter paper and sealed with Parafilm to retain moisture. All rearing was conducted at $28{ }^{\circ} \mathrm{C} 90 \% \mathrm{RH}$ and under a $14: 10 \mathrm{~h}$ photoperiod. Data were collected on larval survival and developmental performance. The final fresh mass of each pupa $( \pm 0.1 \mathrm{mg})$ and the time (days) required to reach pupation was recorded. Leaf consumption was estimated gravimetrically (Wheeler, 2003). Insect frass was 
collected and dried $\left(60{ }^{\circ} \mathrm{C}\right.$ for $\left.48 \mathrm{~h}\right)$ to estimate the approximate digestibility and efficiency of conversion of digested food (Wheeler et al., 2001).

\subsection{Data analysis}

All analyses were conducted with SAS/PC (PROC GLM) unless otherwise noted (SAS Institute Inc., 1990). The leaf moisture, toughness and nitrogen results were analyzed on different leaves and comparisons of regression coefficients of the different species were performed by ANCOVA. The nutritional parameters (e.g., consumption, development time, biomass gain) were analyzed by ANOVA and means were compared with the Ryan's $Q$ test $(P=0.05)$. Percent survival data were analyzed by binomial logistic regression (PROC LOGISTIC). The food digestibility and feeding efficiencies were analyzed by ANCOVA. For food digestion estimates, consumption served as the covariate and the amount of frass served as the response variable. For estimates of efficiency conversion of digested food to insect biomass, the amount of food digested served as the covariate and biomass gain was the response variable (Wheeler et al., 2001). To determine the effect of plant species on food digestibility and conversion efficiencies the estimates obtained from larvae fed $C$. citrina, $C$. viminalis, and $M$. cerifera were compared with those from larvae fed $M$. quinquenervia.

\section{Results}

\subsection{Plant quality}

Leaf percent moisture differed according to leaf position on the stem $\left(F_{1,36}=\right.$ $106.00 ; P<0.0001)$, plant species $\left(F_{3,36}=15.69 ; P<0.0001\right)$, and their interaction $\left(F_{3,36}=27.32 ; P<0.0001\right)$. The lowest percent moisture was found in leaves from $M$. cerifera and the values for this species decreased gradually toward the base of the stem (Fig. 1A). This is in contrast to the percent moisture of leaves from the other three species which increased toward the base. A comparison of regression coefficients of these lines (ANCOVA) indicated that the slope of the $M$. cerifera leaf moisture was significantly less than that of $M$. quinquenervia $(t=7.83$; $P<0.0001)$. Additionally, the height of the regression line for leaf moisture of $M$. cerifera was significantly less than that of $M$. quinquenervia $(t=5.71 ; P<0.0001)$.

Leaf toughness also differed significantly by leaf position $\left(F_{1,68}=205.00\right.$; $P<0.0001)$, plant species $\left(F_{3,68}=49.54 ; P<0.0001\right)$, and their interaction $\left(F_{3,68}=12.26 ; \quad P<0.0001\right)$. The greatest leaf toughness was found with $M$. quinquenervia leaves and this toughness increased toward the base of the branch tip (Fig. 1B). This was in contrast to $C$. viminalis $(t=5.42 ; P<0.0001), C$. citrina $(t=2.71 ; P=0.0086)$, and $M$. cerifera $(t=4.63 ; P<0.0001)$ whose leaf toughness values changed significantly less across the different leaf positions. Additionally, the height of the regression line for leaf toughness of $C$. citrina $(t=4.69 ; P<0.0001)$ and $M$. cerifera $(t=10.27 ; P<0.0001)$ were significantly less than that of $M$. quinquenervia. 
Leaf percent nitrogen (dry mass) was influenced by plant species, but not leaf position or their interaction. The leaves from $M$. cerifera had the greatest nitrogen content and those of $C$. citrina had the lowest nitrogen content compared with those of the other two species (Fig. 2). Similar results were found when the percent nitrogen values were calculated on a fresh mass basis.

The foliar terpenoid constituents of the four plant species were identified by GCMS and their identities were confirmed with authentic standards when available (Table 1). Identities were assigned with matching retention indices (Adams, 2001) and when mass spectra matched $(90 \%$ or greater) those generated with standards on the same instrument or with published spectra (NIST, Wiley, or Adams). All constituents were identified that accounted for $1 \%$ or more of the total chromatogram.

Comparisons of the foliage constituents of the four species indicated that, in terms of presence, those from $M$. cerifera were the most similar to those of M. quinquenervia (Table 1). Of the 32 compounds identified from $M$. quinquenervia leaves, 23 were also found in $M$. cerifera. However, M. cerifera also had the greatest number of unique compounds (7) that were not found in $M$. quinquenervia or the other species. Quantitatively, leaves of $M$. cerifera were dominated most often by $\alpha$-pinene, 1,8-cineole, $\beta$-caryophyllene, $\alpha$-humulene, and $\beta$-selinene. The last two constituents were in much higher concentration than in the leaves of $M$. quinquenervia. The leaves of the two other species, $C$. citrina and $C$. viminalis contained 17 and 18 of the M. quinquenervia constituents, respectively. The leaves of these species contained relatively high concentrations of $\alpha$-pinene, 1,8-cineole, and $\alpha$-terpineol. The leaves of $C$. citrina and $C$. viminalis tested could be distinguished by the presence or absence of $\delta$-cadinene (present only in $C$. viminalis) and caryophyllene oxide (present only in $C$. citrina) and the different concentrations of several constituents including $p$-cymene and $\alpha$-terpineol.

\subsection{Larval survival, growth and development}

\subsubsection{Neonate performance}

Recently emerged larvae ( $<12 \mathrm{~h}$ old) were transferred to fresh tip leaves and monitored for survival, and performance. None of the larvae fed as neonates on $M$. cerifera survived to the prepupal stage, whereas the percent survival of those fed $C$. citrina, $C$. viminalis, and $M$. quinquenervia were equal to or greater than $65 \%$ (Fig. 3A). Larval development time to the prepupal, pupal, and adult stages was greatest for those fed the $C$. citrina leaves (Fig. 3B). Neither the sex of the individuals nor the interaction of sex and the species of plant fed had a significant influence on development time. Biomass gain of the neonates to the prepupal, pupal, and adult stages was significantly influenced only by the sex of the individuals. Females had significantly greater biomass than males in the prepupa (mean $\pm \mathrm{SEM}$; $62.6 \pm 1.2 \mathrm{mg}$ vs. $\left.54.0 \pm 1.2 \mathrm{mg} ; F_{1,39}=21.75 ; P<0.0001\right)$, pupa $(54.3 \pm 1.1 \mathrm{mg}$ vs. $\left.45.0 \pm 1.2 \mathrm{mg} ; F_{1,39}=32.13 ; P<0.0001\right)$, and adult $(47.2 \pm 1.2 \mathrm{mg}$ vs. $37.3 \pm$ $\left.0.8 \mathrm{mg} ; F_{1,39}=36.60 ; P<0.0001\right)$ stages. 


\subsubsection{Third instar performance}

To determine the effect of plant species on older larvae, neonates were initially reared on $M$. quinquenervia leaves during the first two instars and then transferred to their respective test plants until pupation. Survival of these third instars reared to the
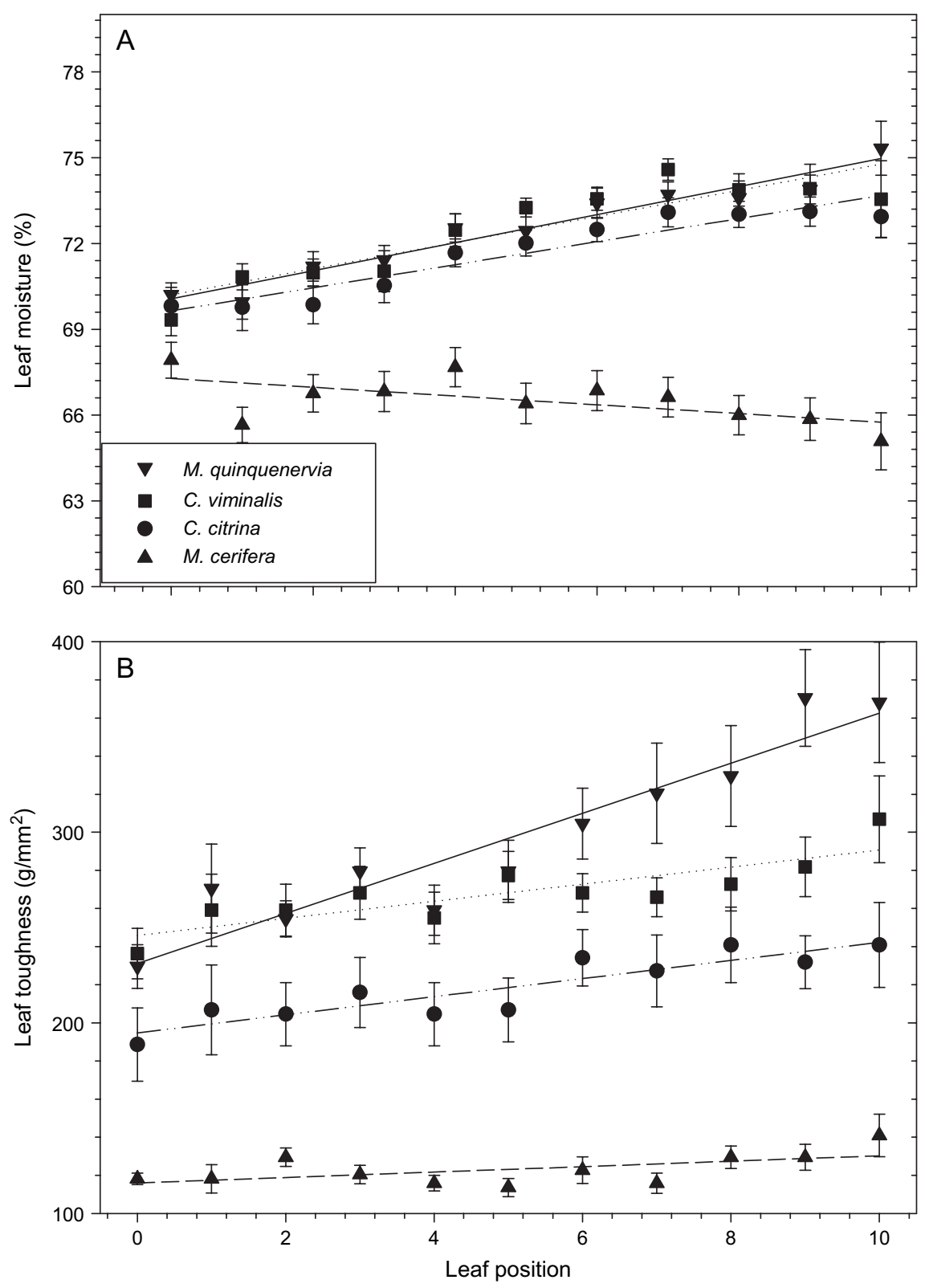


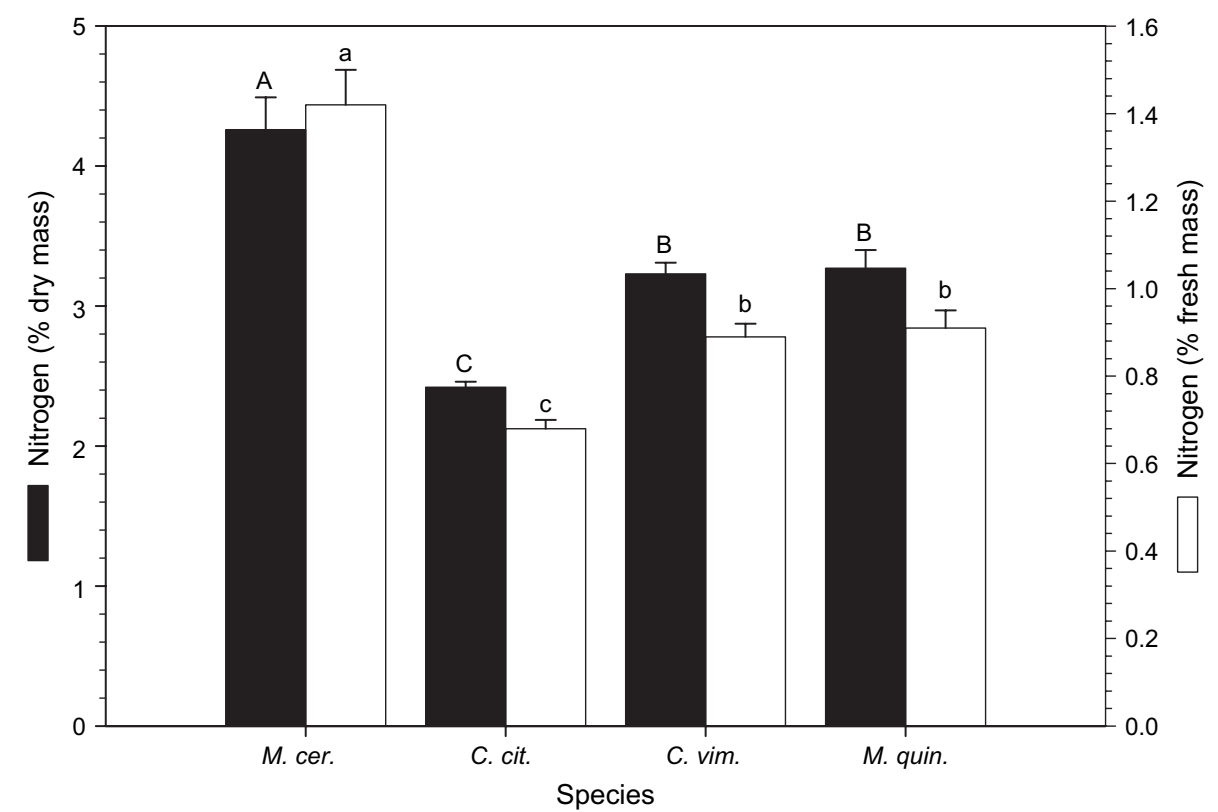

Fig. 2. Mean $( \pm \mathrm{SE})$ leaf percent nitrogen determined on both dry mass (solid bars; $F_{3,35}=18.73$; $P<0.0001)$ and fresh mass (open bars) basis were influenced significantly by plant species. Plant species included M. cerifera (M. cer.), C. citrina (C. cit.), C. viminalis (C. vim.), and M. quinquenervia (M. quin.). Solid bars with the same uppercase letters (dry mass) or open bars with the same lowercase letters (fresh mass) did not differ significantly according to a Ryan's $Q$ mean comparison test $(P=0.05)$.

adult stage was significantly reduced only for those fed the $M$. cerifera leaves $(20 \% \pm 11.6 \%)$ compared with those fed leaves of C. citrina $(75.0 \pm 9.6 \%)$, C. viminalis $(67.5 \pm 7.5 \%)$, and $M$. quinquenervia $(81.7 \pm 6.9 \%)$ (Fig. 4A). Larval food consumption estimated on a dry mass $(121.5 \pm 5.4 \mathrm{mg})$ and a fresh mass $(439.4 \pm 20.6 \mathrm{mg})$ basis was not significantly different when fed the leaves from the different plant species (Fig. 4B). Development time of the third instars to the prepupal stage was greater in those fed leaves of $M$. cerifera $(11.4 \pm 0.9 \mathrm{~d})$ and

Fig. 1. Mean $( \pm$ SE) leaf percent moisture (A) and leaf toughness (B) of the fresh tips of different species from the apical tip (number 0) toward the base of the stem. The regression line coefficients for height and slope of leaf percent moisture for M. cerifera $\left(y=67.3-0.2 x ; r^{2}=0.37 ; P=0.0492\right)$ were significantly less $(t=5.71 ; P<0.0001$ and $t=7.83 ; P<0.0001$, respectively) than those for $M$. quinquenervia (B) $\left(y=70.1+0.5 x ; r^{2}=0.95 ; P<0.0001\right)$. The regression coefficients for leaf percent moisture for C. viminalis $\left(y=70.2+0.5 x ; r^{2}=0.81 ; P=0.0002\right)$ and $C$. citrina $\left(y=69.6+0.4 x ; r^{2}=0.90\right.$; $P<0.0001)$ did not differ significantly from those of $M$. quinquenervia. The height of the regression line for leaf toughness for $M$. cerifera $\left(y=104.9+3.5 x ; r^{2}=0.69 ; P<0.0001\right)$ and that of $C$. citrina $\left(y=181.1+6.4 x ; r^{2}=0.79 ; P<0.0001\right)$ were significantly less $(t=10.27 ; P<0.0001$ and $t=4.69$; $P<0.0001$, respectively) than that of $M$. quinquenervia $\left(y=238.3+9.2 x ; r^{2}=0.86 ; P<0.0001\right)$, however, the regression line height for leaf toughness for $C$. viminalis $\left(y=246.2+3.7 x ; r^{2}=0.66\right.$; $P<0.0001)$ did not differ from that of $M$. quinquenervia. 
Table 1

Mean percent $( \pm \mathrm{SE}$ ) concentration of all constituents identified by GC and GC-MS from flush leaves of $M$. quinquenervia $(n=10), C$. citrina $(n=6), C$. viminalis $(n=6)$, and M. cerifera $(n=5)$

\begin{tabular}{|c|c|c|c|c|c|c|c|c|c|c|c|c|}
\hline \multirow[t]{2}{*}{ Compounds } & \multicolumn{3}{|c|}{ M. quinquenervia ${ }^{\mathrm{a}}$} & \multicolumn{3}{|c|}{ C. citrina } & \multicolumn{3}{|c|}{ C. viminalis } & \multicolumn{3}{|c|}{ M. cerifera } \\
\hline & $\overline{n^{\mathrm{b}}}$ & $\%$ & $\mathrm{SE}$ & $\bar{N}$ & $\%$ & $\mathrm{SE}$ & $\bar{n}$ & $\%$ & $\mathrm{SE}$ & $\bar{n}$ & $\%$ & $\mathrm{SE}$ \\
\hline$\alpha$-Thujene ${ }^{c}$ & 10 & 0.04 & 0 & 6 & 1.23 & 0.36 & 6 & 0.25 & 0.06 & 5 & 0.31 & 0.05 \\
\hline$\alpha$-Pinene & 10 & 5.99 & 0.52 & 6 & 15.13 & 2.42 & 6 & 20.92 & 5.8 & 5 & 27.5 & 4.83 \\
\hline Benzaldehyde & - & - & - & - & - & - & - & - & - & 5 & 0.1 & 0.02 \\
\hline Sabinene & 9 & 0.08 & 0.02 & 2 & 1.11 & 0.56 & 3 & 0.26 & 0.02 & 4 & 0.27 & 0.03 \\
\hline$\beta$-Pinene & 10 & 2.96 & 0.19 & 6 & 1.91 & 0.37 & 6 & 1.7 & 0.23 & 5 & 1.22 & 0.14 \\
\hline Myrcene & 10 & 1.46 & 0.12 & 5 & 0.77 & 0.28 & 6 & 1.18 & 0.07 & 5 & 0.22 & 0.03 \\
\hline$\alpha$-Phellandrene & 7 & 0.03 & 0 & 6 & 1.53 & 0.52 & 6 & 0.72 & 0.25 & - & - & - \\
\hline$\alpha$-Terpinene & 4 & 0.06 & 0.02 & - & - & - & - & - & - & - & - & - \\
\hline$p$-Cymene ${ }^{c}$ & 10 & 0.02 & 0 & 6 & 5.97 & 1.27 & 6 & 0.71 & 0.09 & 5 & 2.55 & 1.98 \\
\hline Limonene & 10 & 6.77 & 0.26 & 6 & 4.67 & 0.21 & 6 & 4.42 & 0.59 & 5 & 1.41 & 0.28 \\
\hline 1,8-Cineole ${ }^{\mathrm{c}}$ & 10 & 28.58 & 3.15 & 6 & 58.59 & 3.18 & 6 & 60.35 & 9.36 & 5 & 3.2 & 0.92 \\
\hline$\gamma$-Terpinene & 10 & 0.5 & 0.03 & - & - & - & - & - & - & 5 & 4.13 & 0.77 \\
\hline Terpinolene & 10 & 0.25 & 0.02 & 1 & 0.17 & & 1 & 0.08 & & 4 & 0.21 & 0.03 \\
\hline Linalool & 10 & 0.13 & 0.01 & 6 & 0.88 & 0.13 & 6 & 0.37 & 0.04 & 5 & 1.18 & 0.1 \\
\hline Terpinen 4-ol & 10 & 0.51 & 0.03 & 5 & 1.11 & 0.12 & 4 & 0.44 & 0.12 & 4 & 0.21 & 0.07 \\
\hline$\alpha$-Terpineol & 10 & 8.66 & 0.93 & 6 & 4.74 & 0.88 & 6 & 1.72 & 0.12 & 5 & 4.13 & 0.77 \\
\hline$\alpha$-Copaene & 10 & 0.17 & 0.01 & - & - & - & 3 & 0.48 & 0.08 & 5 & 0.29 & 0.06 \\
\hline$\beta$-Elemene ${ }^{\mathrm{d}}$ & - & - & - & - & - & - & - & - & - & 5 & 2.72 & 0.88 \\
\hline$\alpha$-Gurjunene & 10 & 0.55 & 0.05 & - & - & - & - & - & - & - & - & - \\
\hline$\beta$-Caryophyllene & 10 & 6.53 & 0.56 & 6 & 1.09 & 0.07 & 3 & 0.21 & 0.05 & 5 & 16.74 & 3.88 \\
\hline$E$ - $\alpha$-bergamotene ${ }^{\mathrm{d}}$ & - & - & - & - & - & - & - & - & - & 5 & 1.52 & 0.15 \\
\hline$(+)$-Aromadendrene & 10 & 0.18 & 0.01 & 1 & 0.44 & & 6 & 0.6 & 0.06 & - & - & - \\
\hline$\alpha$-Humulene & 10 & 0.9 & 0.08 & - & - & - & - & - & - & 5 & 9.59 & 1.12 \\
\hline (-)-Alloaromadendrene & 10 & 1.12 & 0.1 & 1 & 0.37 & & 6 & 0.52 & 0.04 & 4 & 0.3 & 0.06 \\
\hline$\alpha$-Curcumene ${ }^{\mathrm{d}}$ & - & - & - & - & - & - & - & - & - & 5 & 1.77 & 0.23 \\
\hline Germacrene $\mathrm{D}^{\mathrm{d}}$ & - & - & - & - & - & - & - & - & - & 5 & 5.1 & 1.32 \\
\hline$\beta$-Selinene ${ }^{\mathrm{d}}$ & 10 & 1.21 & 0.14 & - & - & - & - & - & - & 5 & 8.53 & 3.41 \\
\hline$\alpha$-Selinene ${ }^{\mathrm{d}}$ & 10 & 0.56 & 0.05 & - & - & - & - & - & - & 5 & 4.51 & 0.27 \\
\hline$\beta$-Bisabolene ${ }^{\mathrm{d}}$ & - & - & - & - & - & - & - & - & - & 5 & 2.99 & 0.28 \\
\hline$\gamma$-Cadinene ${ }^{\mathrm{d}}$ & 10 & 0.65 & 0.06 & - & - & - & - & - & - & 5 & 0.66 & 0.44 \\
\hline$\delta$-Cadinene & 10 & 0.87 & 0.08 & - & - & - & 6 & 0.3 & 0.13 & 5 & 0.52 & 0.11 \\
\hline$E$-nerolidol & - & - & - & - & - & - & - & - & - & 5 & 2.55 & 0.78 \\
\hline $\begin{array}{l}\text { 2,4-Dihydroxy-6- } \\
\text { methoxytoluene }\end{array}$ & 10 & 1.38 & 0.04 & - & - & - & - & - & - & - & - & - \\
\hline Caryophyllene oxide & 10 & 2.28 & 0.27 & 5 & 2.6 & 0.3 & - & - & - & 5 & 0.82 & 0.35 \\
\hline Globulol & 10 & 0.36 & 0.03 & - & - & - & - & - & - & - & - & - \\
\hline Viridiflorol & 10 & 26.27 & 2.43 & - & - & - & - & - & - & - & - & - \\
\hline Epi- $\alpha$-cadinol $^{\mathrm{d}}$ & 10 & 0.55 & 0.06 & - & - & - & - & - & - & - & - & - \\
\hline$\beta$-Eudesmol & 10 & 0.33 & 0.09 & - & - & - & - & - & - & - & - & - \\
\hline$\alpha-$ Cadinol $^{\mathrm{d}}$ & 10 & 0.31 & 0.02 & - & - & - & - & - & - & - & - & - \\
\hline
\end{tabular}

Constituents quantified on the DB-17MS column, unless otherwise noted. Rows with italic values contain the major constituents ( $>5 \%$ ) found in $M$. quinquenervia foliage.

a Dash indicates compound was not detected.

b Number of plants where the constituent was detected.

c Constituents quantified on the HP-5MS column.

$\mathrm{d}$ Tentative assignments as identification was based on matching spectra and retention index but no standard was available for comparison. 

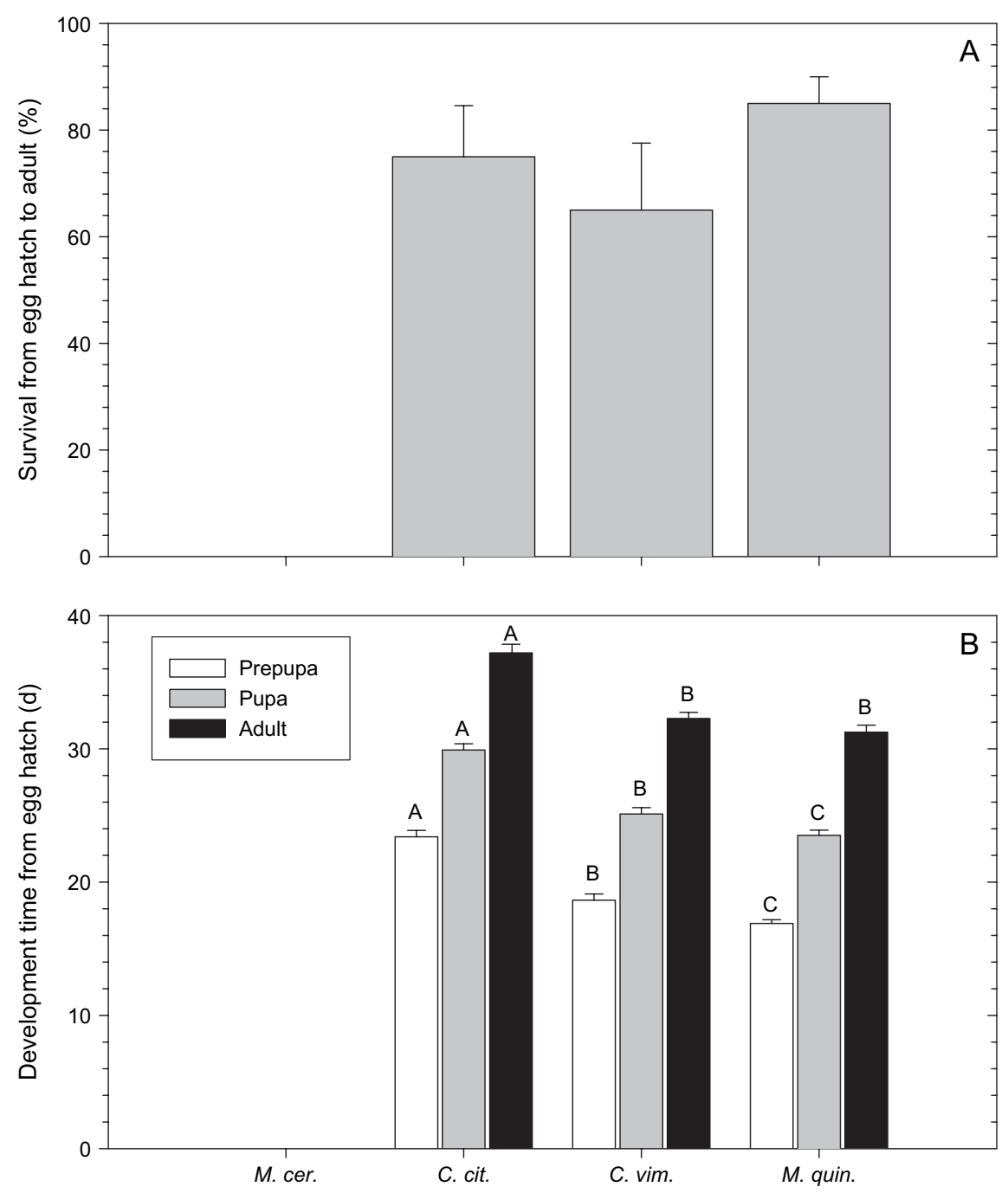

Fig. 3. Mean $( \pm$ SE) percent survival (A) and development time (B) of $O$. vitiosa neonates to the adult stage when fed leaves from $M$. cerifera $(M$. cer.), C. citrina (C. cit.), C. viminalis $(C$. vim.), or $M$. quinquenervia (M. quin.). No neonates survived when fed $M$. cerifera leaves and the percent survival of the larvae fed the other species did not differ significantly. Larval development time to the prepupal $\left(F_{2,39}=62.51 ; P<0.0001\right)$, pupal $\left(F_{2,39}=50.77 ; P<0.0001\right)$, and adult $\left(F_{2,39}=30.71 ; P<0.0001\right)$ stages was greatest for those fed the $C$. citrina leaves. Bars describing the same stage with the same fill and uppercase letters did not differ significantly according to a Ryan's $Q$ mean comparison test $(P=0.05)$.

C. citrina $(10.8 \pm 0.2 \mathrm{~d})$ compared with those fed leaves of the other two plant species (Fig. 4C). Biomass gain was reduced only for those larvae fed leaves of $M$. cerifera where the larvae gained $19.8( \pm 3.2 \mathrm{mg}$; Fig. 4D). As in the previous study where larvae were reared from neonates, the sex of the prepupae $\left(F_{1,43}=23.0 ; P<0.0001\right)$, 


pupae $\left(F_{1,43}=31.7 ; P<0.0001\right)$, and adults $\left(F_{1,43}=39.7 ; P<0.0001\right)$ significantly influenced their biomass (excluding those fed $M$. cerifera as all neonates died), regardless of larval diet. Female prepupal $(62.6 \pm 1.2 \mathrm{mg})$, pupal $(54.3 \pm 1.1 \mathrm{mg})$, and adult $(47.2 \pm 1.2 \mathrm{mg})$ biomass were all greater than those of males $(54.0 \pm$ $1.2 \mathrm{mg} ; 45.0 \pm 1.2 \mathrm{mg} ; 37.3 \pm 0.8 \mathrm{mg}$, respectively).

To determine the effect of larval diet on food digestion, frass production was analyzed at different levels of consumption. Greater frass production at a given level of consumption would indicate a relatively low level of food digestion. As used here, digestion includes both food digestion and absorbance. Frass production increased with greater food consumption for all larvae fed from the third instar to the prepupal stage regardless of the plant species (Fig. 5). The ANCOVA indicated that the covariate consumption was significant, as was the interaction between this and plant species indicating significant slope differences. Slope comparisons indicated that digestion of the $M$. cerifera leaves by $O$. vitiosa larvae was significantly reduced, as indicated by the increased frass production, compared with larvae fed the $M$. quinquenervia leaves. These results indicate that consumption of $M$. cerifera leaves may interfere with digestion and/or absorption of ingested food by $O$. vitiosa larvae.

Once the food is digested and absorbed a percentage is converted to growth while the remainder is used as fuel for metabolic processes. If the larvae are fed a toxic diet more digested food resources are allocated to metabolism resulting in decreased growth. To determine the effect of the larval diets on the efficiency of conversion of the digested food to growth, larval biomass gain was determined at a range of food digestion levels (Fig. 6). The ANCOVA indicated that species and the covariate consumption were both significant, however, the interaction between the two was not indicating differences that occurred in biomass gain. When the covariateadjusted biomass gain values were compared larvae fed the $M$. cerifera leaves had significantly reduced values compared with those fed the $M$. quinquenervia leaves.

\section{Discussion}

Even though this biological control species is apparently highly selective in its feeding and oviposition it is not surprising, considering their similar secondary metabolites, to find acceptance and development on species of a related Australian genus. The members of the Callistemon spp. tested here are related taxonomically to the target weed M. quinquenervia, and considered by some (Byrnes, 1986; Craven, 1999) members of the Melaleuca genus. Not only are these species close taxonomic

Fig. 4. Mean ( \pm SE) larval survival ( $\%)$, consumption (mg dry mass), development time to the prepupal stage (d), and biomass gain ( $\mathrm{mg}$ ) of $O$. vitiosa when fed leaves from M. cerifera, C. citrina, C. viminalis, and $M$. quinquenervia. Survival was significantly reduced for larvae fed $M$. cerifera compared with those fed the $M$. quinquenervia leaves $\left(X_{3}^{2}=21.4 ; P<0.0001\right)$. Consumption was not significantly influenced by plant species. Development time was significantly greater for larvae fed $M$. cerifera and $C$. citrina $\left(F_{3,59}=15.15\right.$; $P<0.0001)$. Prepupal biomass gain was significantly reduced in larvae fed $M$. cerifera $\left(F_{3,58}=9.59 ;\right.$ $P<0.0001)$. Bars with the same lowercase letters within a graph did not differ significantly according to a Ryan's $Q$ mean comparison test $(P=0.05)$. 


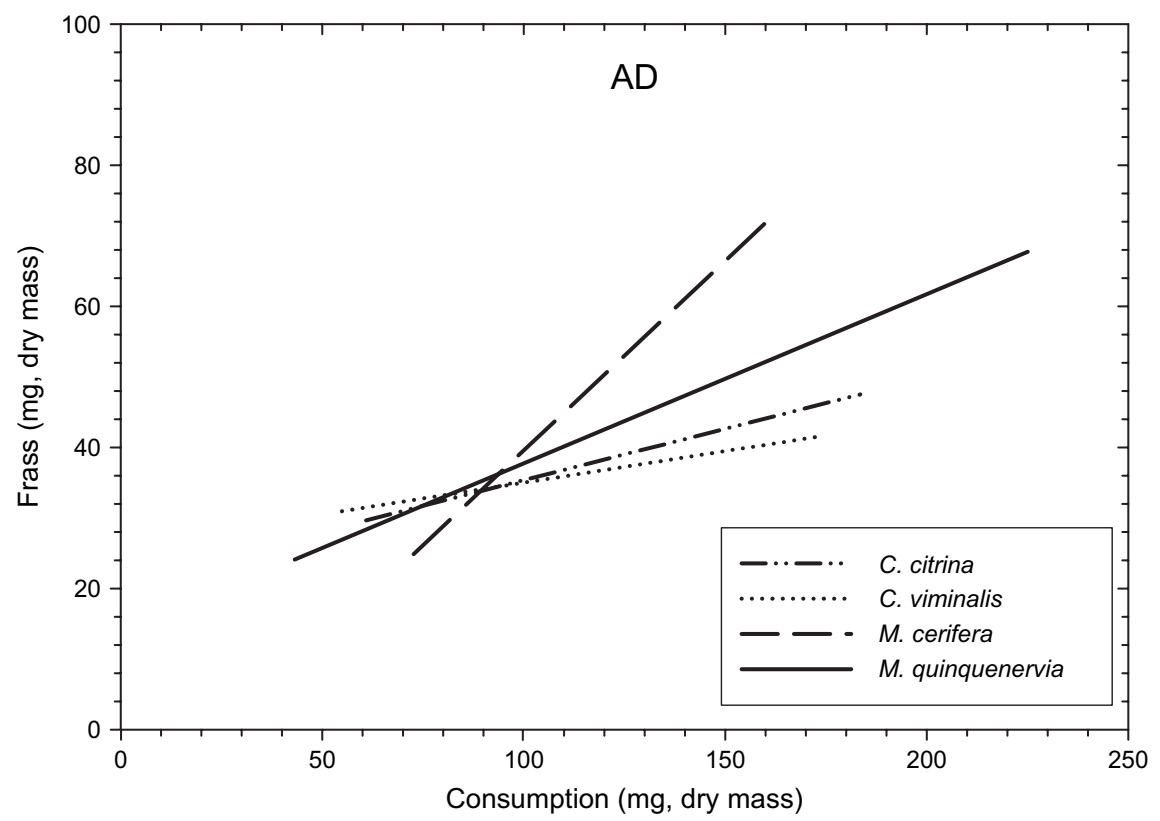

Fig. 5. Mean $( \pm \mathrm{SE})$ larval frass production across a range of consumption levels by $O$. vitiosa larvae fed from the third instar to the prepupal stage leaves of one of four plant species. This analysis approximates the digestibility (AD) of leaves from each plant species; as more frass was produced less food was available for digestion. Although the species effect was not significant $(P>0.2)$, the covariate consumption $\left(F_{1,40}=29.48 ; P<0.0001\right)$ was, as was the interaction between the two $\left(F_{3,40}=3.01 ; P=0.0411\right)$. The slope of the line for frass produced by larvae fed the $M$. cerifera leaves was significantly greater $(t=2.12$; $P=0.0400$ ) than that of larvae fed the $M$. quinquenervia leaves.

relatives but their terpenoid profiles, as shown here, are also similar to those of the target weed, containing 17 and 18 of the $32 \mathrm{M}$. quinquenervia constituents identified. The list of constituents found here is generally confirmed by others that have analyzed C. viminalis (Brophy et al., 1985, 1997; Wheeler et al., 2003), C. citrina (Wheeler et al., 2003), and M. cerifera (Halim and Collins, 1973; Bello et al., 1996) leaves. Feeding and development by the $O$. vitiosa third instars on the North American M. cerifera was more surprising considering these species are unrelated. However, the similarity in terpenoids of the leaves from $M$. quinquenervia and $M$. cerifera may explain this response. Probably one or more of these constituents stimulated sensillae in $O$. vitiosa larvae that invoked a feeding response. Consumption of the leaves of this species, though high in nitrogen and soft, resulted in $100 \%$ neonate mortality and $80 \%$ third instar mortality, possibly due to the presence of several unique terpenoids not found in M. quinquenervia leaves.

Predicting the host range of a potential biological control species is a fundamental step in the development of a new agent. The results of host range tests are used to estimate the potential risk to non-target species posed by releasing the agent. A major concern is that once released the biological control agent will expand its range beyond that which was predicted from the host testing results. Host range 


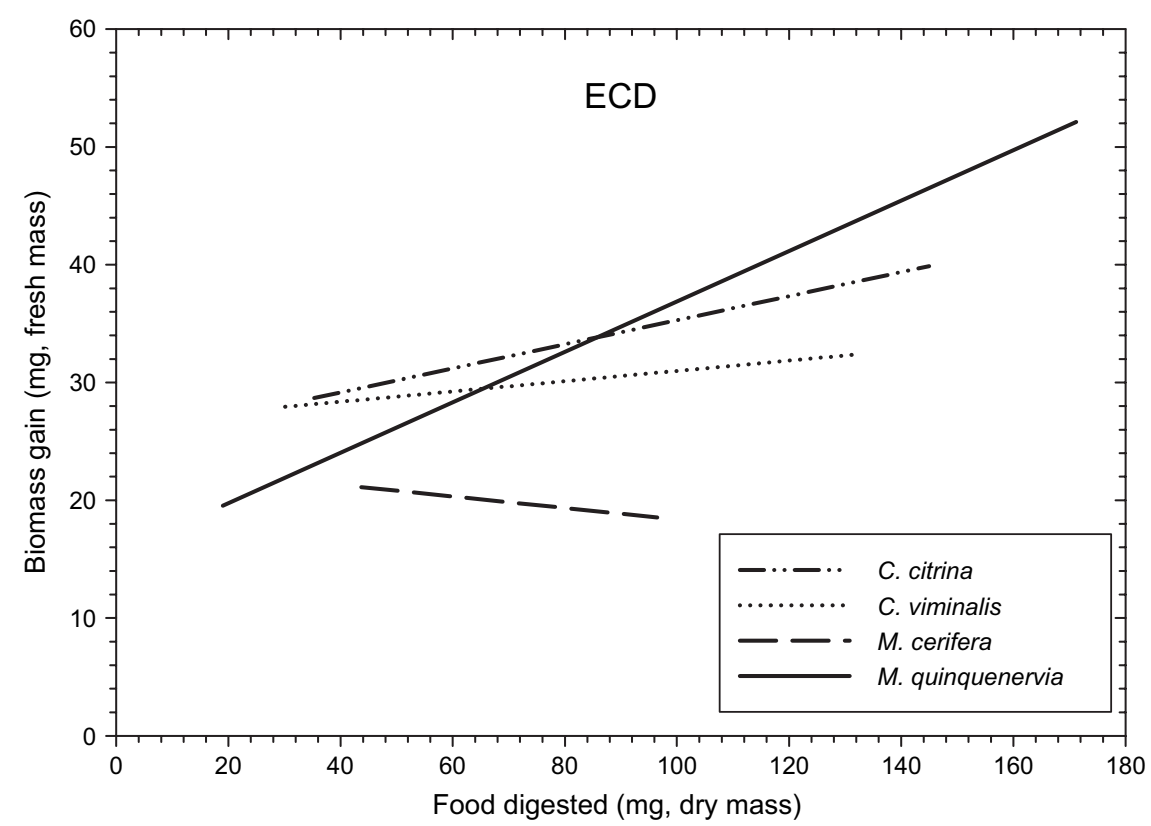

Fig. 6. Mean $( \pm \mathrm{SE})$ larval biomass gain across a range of food digestion levels by larvae fed from the third instar to the prepupal stage leaves from one of four plant species. This analysis compares the efficiency of the conversion of digested food (ECD) by larvae fed leaves of different species. The effect species $\left(F_{3,43}=2.62 ; P=0.0627\right)$ and the covariate consumption $\left(F_{1,43}=7.76 ; P=0.0079\right)$ were both significant, however, the interaction between the two was not $(P>0.3)$. When the covariate-adjusted biomass gain was compared larvae fed the $M$. cerifera leaves $(21.1 \pm 4.0 \mathrm{mg})$ were significantly $(t=2.58$; $P=0.0135)$ reduced compared with those fed the $M$. quinquenervia $(33.2 \pm 2.4 \mathrm{mg})$ leaves.

expansions in nature have generally been restricted to plant species of the same taxon, such as to the same genus (Horton et al., 1988) or family (Bush, 1975; Tabashnik, 1983). Host expansions by insects introduced for weed biological control over the past 90 years have been few. Like insect herbivores in general, those few weed biological control agents that have expanded their host range have done so to closely related species within the same family or genus (Pemberton, 2000). The results reported here confirm the results obtained during quarantine host testing indicating that the only potential non-target species threatened by this species are the close relatives, the ornamental Australian Callistemon species. All results have indicated that the native species $M$. cerifera is not a physiological host, as none of the first instars complete development when fed this species. Furthermore, quarantine results indicated that no oviposition was found by $O$. vitiosa on $M$. cerifera (Balciunas and Buckingham, 1996). Thus, the only potential damage to this native plant in natural conditions may occur as 'spill-over' from larvae feeding on neighboring $M$. quinquenervia. Since the release of this biological control agent in 1997, no such damage to $M$. cerifera has been observed despite systematic field observations (P. Pratt, USDA/ARS, Ft Lauderdale, FL, unpublished data). 
Moreover, as predicted from quarantine host testing and the data reported here, $O$. vitiosa larvae are frequently found on ornamental populations of the Australian Callistemon spp. Finally, the geographic range of $M$. cerifera extends north from southern Florida to New Jersey and west to southern Texas (Small, 1972), whereas that of $M$. quinquenervia is restricted to central and south Florida (Turner et al., 1998). Thus any threat to $M$. cerifera is limited to the geographic range where the two species overlap.

Analysis of the plant quality factors may explain how some species are physiological hosts while others only elicit behavioral responses, like feeding and oviposition. The leaf toughness and percent nitrogen in $M$. cerifera indicated that this species had the softest leaves and the highest nitrogen content of those species measured. Additionally, the relatively low percent moisture of these leaves indicates that the foliar nutrients were less diluted than those of the other three species. Conversely, it is possible that the low water content of the leaves could have a negative effect on the performance of herbivores (Scriber and Feeny, 1979). The terpenoid analysis of the leaves of $M$. cerifera indicates that many of the same constituents found in the $M$. quinquenervia leaves were also present in leaves of the other three species. Such major components as $\alpha$-pinene, 1,8-cineole, limonene, $\alpha$-terpineol, $\beta$-caryophyllene that were shared by all species may individually or collectively constitute feeding elicitors. A chemical variant or chemotype of M. quinquenervia exists (Ireland et al., 2002; Wheeler et al., 2003) that has high concentrations of another terpenoid $E$-nerolidol. This compound was also found in $M$. cerifera leaves and in both species may elicit feeding behavior in $O$. vitiosa larvae. The presence of several major components unique in this study to $M$. cerifera leaves such as $\beta$-elemene, $E$ - $\alpha$-bergamotene, $\alpha$-curcumene, germacrene $\mathrm{D}$ and the relatively high concentrations of $\alpha$-humulene and $\beta$-selinene may explain why this is not a physiological host. Several of these unique compounds are known to be associated with various biological activities in insects, such as $\beta$-elemene (Peterson et al., 2002), $E$ - $\alpha$-bergamotene (Schmelz et al., 2001), $\alpha$-curcumene (Agarwal et al., 2001; McBrien et al., 2002), germacrene D (Innocenzi et al., 2001; Kalberer et al., 2001; Stranden et al., 2003), $\beta$-eudesmol (Sogabe et al., 2000), and $\beta$-selinene, (Quintana et al., 2003; Weissbecker et al., 1999). The decreased digestibility (AD) and assimilation efficiency (ECD) found here are indications of the toxic effect of one or more of these unique constituents. Although feeding elicitors may be present in $M$. cerifera, the high larval mortality suggests one or more of these unique compounds could act as metabolic toxins which were not successfully detoxified by the larvae.

In the initial stages in a weed biological control program a test plant list is compiled to predict the host range of a potential agent when offered desirable plant species. This list incorporates species that are of economic and ecologic importance. Moreover, species are included that are taxonomically related to the weed species being controlled as these are thought to be most at risk (Wapshere, 1974). If this practice had been followed exclusively with the $M$. quinquenervia biological control project, the native $M$. cerifera would not have been included in the test list as it is not related to the weed. This species was only included because it commonly co-occurs with $M$. quinquenervia and any agents released against the weed would likely 
encounter this native species (G. Buckingham, personal communication). Other insect herbivores being developed for biological control of $M$. quinquenervia also respond similarly to $M$. cerifera (Buckingham, 2001; Wineriter et al., 2003). Though complete development of these agents did not occur, M. cerifera apparently has at least some of the behavioral cues that are relevant to these $M$. quinquenervia specialists. These results need to be considered in a broader context for all biological control projects. When developing quarantine protocols for weed biological control, test plant species need to be considered that share similar chemistry, not just taxonomy. Such additions would include plant species, regardless of taxonomic affiliation, that contain the host recognition cues most relevant to specialist herbivore species making decisions of where to oviposit and begin feeding (Schaffner, 2001).

\section{Acknowledgments}

I am indebted to the technical assistance of Luke Kasarjian, Rosa Leidi-Ferrer, USDA/ARS, Ft Lauderdale, FL, Mark Endries, Lisa Massey, Kelly MacDonald, AmeriCorps, Student Conservation Association and Drs. S. J. Franks, USDA/ARS, R. van Klinken, CSIRO, Australia and U. Schaffner, CABI, Switzerland for valuable comments on a previous draft of this manuscript. Chemical standards were generously donated by Dr. I. A. Southwell, NSW Agriculture, Wollongbar Agricultural Institute, NSW, Australia. The identity of the species of Myrtaceae included here was confirmed by Dr. L. Craven, Australian National Herbarium, Canberra, Australia. Financial support was provided by Florida Department of Environmental Protection, Dade County Department of Environmental Resource Management, and USDA/ARS TAME Melaleuca Area Wide Project.

\section{References}

Adams, R.P., 2001. Identification of Essential Oil Components by Gas Chromatography/Quadrupole Mass Spectroscopy. Allured Publishing Corp., Carol Stream, IL.

Agarwal, M., Walia, S., Dhingra, S., Khambay, B.P.S., 2001. Insect growth inhibition, antifeedant and antifungal activity of compounds isolated/derived from Zingiber officinale Roscoe (ginger) rhizomes. Pest Management Science 57, 289-300.

Balciunas, J.K., Buckingham, G.R., 1996. Release of the Australian weevil Oxyops vitiosa for control of melaleuca, Melaleuca quinquenervia. Unpublished Report Submitted to TAG for Release of Biological Control Agent, 23 pp.

Balciunas, J.K., Burrows, D.W., Purcell, M.F., 1994. Field and laboratory host ranges of the Australian weevil, Oxyops vitiosa (Coleoptera: Curculionidae), a potential biological control agent for the paperbark tree, Melaleuca quinquenervia. Biological Control 4, 351-360.

Becerra, J.X., 1997. Insects on plants: macroevolutionary chemical trends in host use. Science 279, $253-256$.

Bello, A., Rodriquez, M.L., Castineiras, N., Urquiola, A., Rosado, A., Pino, J.A., 1996. Chemical composition of the leaf oil of Myrica cerifera L. growing in western Cuba. The Journal of Essential Oil Research 8, 215-216.

Bernays, E.A., Graham, M., 1988. On the evolution of host specificity in phytophagous arthropods. Ecology 69, 886-892. 
Briese, D.T., Zapata, A., Andorno, A., Perez-Camargo, G., 2002. A two-phase open-field test to evaluate the host-specificity of candidate biological control agents for Heliotropium amplexicaule. Biological Control 25, 259-272.

Brophy, J.J., Lassak, E.V., Toia, R.F., 1985. The volatile leaf oils of two cultivars of Callistemon viminalis. Journal and Proceedings of the Royal Society of New South Wales 118, 101-104.

Brophy, J.J., Boland, D.J., Lassak, E.V., 1989. Leaf essential oils of Melaleuca and Leptospermum species from tropical Australia. In: Boland, D.J. (Ed.), Trees for the Tropics: Growing Australian Multipurpose Trees and Shrubs in Developing Countries. Australian Centre for International Agricultural Research, Canberra, Australia, pp. 193-203.

Brophy, J.J., Forster, P.I., Punruckvong, A., 1997. Variation in Callistemon viminalis (Myrtaceae): new evidence from leaf essential oils. Australian Systematic Botany 10, 1-13.

Buckingham, G.R., 2001. Quarantine host range studies with Lophyrotoma zonalis, an Australian sawfly of interest for biological control of melaleuca, Melaleuca quinquenervia, in Florida, USA. Biocontrol 46, 363-386.

Bush, G.L., 1975. Modes of animal speciation. Annual Review of Ecology and Systematics 6, 339-364.

Byrnes, N.B., 1986. A revision of Melaleuca L. (Myrtaceae) in northern and eastern Australia 3. Austrobaileya 2, 254-273.

Center, T.D., Van, T.K., Rayachhetry, M., Buckingham, G.R., Dray, F.A., Wineriter, S.A., Purcell, M.F., Pratt, P.D., 2000. Field colonization of the melaleuca snout beetle (Oxyops vitiosa) in south Florida. Biological Control 19, 112-123.

Craven, L.A., 1999. Behind the names: the botany of tea tree, Cajuput and Niaouli. In: Southwell, I.A., Lowe, R. (Eds.), Tea Tree: The Genus Melaleuca. Harwood Academic Publ., Australia, pp. 11-28.

Ehrlich, P.R., Raven, P.H., 1964. Butterflies and plants: a study in coevolution. Evolution 18, 586-608.

Gershenzon, J., Croteau, R., 1991. Terpenoids. In: Rosenthal, G.A., Berenbaum, M. (Eds.), Herbivores: Their Interactions with Secondary Plant Metabolites, second ed. The Chemical Participants, vol. I. Academic Press, San Diego, CA, pp. 165-219.

Halim, A.F., Collins, R.P., 1973. Essential oil analysis of the Myricaceae of the Eastern United States. Phytochemistry 12, 1077-1083.

Horton, D.R., Capinera, J.L., Chapman, P.L., 1988. Local differences in host use by two populations of the Colorado potato beetle. Ecology 69, 823-831.

Innocenzi, P.J., Hall, D.R., Cross, J.V., 2001. Components of male aggregation pheromone of strawberry blossom weevil, Anthonomus rubi Herbst. (Coleoptera: Curculionidae). Journal of Chemical Ecology 27, 1203-1218.

Ireland, B.F., Hibbert, D.B., Goldsack, R.J., Doran, J.C., Brophy, J.J., 2002. Chemical variation in the leaf essential oil of Melaleuca quinquenervia (Cav.) S.T. Blake. Biochemical Systematics and Ecology $30,457-470$.

Kalberer, N.M., Turlings, T.C.J., Rahier, M., 2001. Attraction of a leaf beetle (Oreina cacaliae) to damaged host plants. Journal of Chemical Ecology 27, 647-661.

Langenheim, J.H., 1994. Higher plant terpenoids: a phytocentric overview of their ecological roles. Journal of Chemical Ecology 20, 1223-1280.

McBrien, H.L., Millar, J.G., Rice, R.E., McElfresh, J.S., Cullen, E., Zalom, F.G., 2002. Sex attractant pheromone of the red-shouldered stink bug Thyanta pallidovirens: a pheromone blend with multiple redundant components. Journal of Chemical Ecology 28, 1797-1818.

McFadyen, R.E., 1998. Biological control of weeds. Annual Review of Entomology 43, 369-393.

Mitter, C., Farrell, B., 1991. Macroevolutionary aspects of insect-plant interactions. In: Bernays, E. (Ed.), Insect-Plant Interactions, vol. 3. CRC Press, Boca Raton, FL, pp. 35-78.

Pemberton, R.W., 2000. Predictable risk to native plants in weed biological control. Oecologia 125, 489-494.

Peterson, C., Zhu, J.W., Coats, J.R., 2002. Identification of components of Osage orange fruit (Maclura pomifera) and their repellency to German cockroaches. Journal of Essential Oil Research 14, 233-236.

Quintana, A., Reinhard, J., Faure, R., Uva, P., Bagneres, A.G., Massiot, G., Clement, J.L., 2003. Interspecific variation in terpenoid composition of defensive secretions of European Reticulitermes termites. Journal of Chemical Ecology 29, 639-652.

SAS Institute Inc., 1990. SAS/STAT User's Guide. Version 6. SAS Institute, Cary, NC. 
Schaffner, U., 2001. Host range testing of insects for biological weed control: how can it be better interpreted? Bioscience 51, 951-959.

Schmelz, E.A., Alborn, H.T., Tumlinson, J.H., 2001. The influence of intact-plant and excised-leaf bioassay designs on volicitin- and jasmonic acid-induced sesquiterpene volatile release in Zea mays. Planta 214, 171-179.

Schoonhoven, L.M., Jermy, T., Van Loon, J.J.A., 1998. Insect-Plant Biology. Chapman \& Hall, London.

Scriber, J.M., Feeny, P.P., 1979. Growth of herbivorous caterpillars in relation to feeding specialization and to the growth form of their food plants. Ecology 60, 829-850.

Small, J.K., 1972. Manual of the Southeastern Flora. Hafner Publishing Co., New York.

Sogabe, A., Kinjo, K., Abe, F., Yamauchi, T., Yaga, S., 2000. Termiticidal substances from the heartwood of Cryptomeria japonica D. Don. Mokuzai Gakkaishi 46, 124-131.

Stadler, E., 1992. Behavioral responses of insects to plant secondary compounds. In: Rosenthal, G.A., Berenbaum, M. (Eds.), Herbivores, Their Interactions with Secondary Plant Metabolites, second ed. Academic Press, San Diego, pp. 45-88.

Stranden, M., Liblikas, I., Konig, W.A., Almaas, T.J., Borg-Karlson, A.K., Mustaparta, H., 2003. (-)-Germacrene D receptor neurones in three species of heliothine moths: structure-activity relationships. Journal of Comparative Physiology A 189, 563-577.

Tabashnik, B.E., 1983. Host range evolution: The shift from native legume hosts to alfalfa by the butterfly, Colias philodice eriphyle. Evolution 37, 150-162.

Turner, C.E., Center, T.D., Burrows, D.W., Buckingham, G.R., 1998. Ecology and management of Melaleuca quinquenervia, an invader of wetlands in Florida, U.S.A. Wetlands Ecology and Management 5, 165-178.

Wahlberg, N., 2001. The phylogenetics and biochemistry of host-plant specialization in melitaeine butterflies (Lepidoptera: Numphalidae). Evolution 55, 522-537.

Wapshere, A.J., 1974. A strategy for evaluating the safety of organisms for biological weed control. The Annals of Applied Biology 77, 201-211.

Weissbecker, B., Van Loon, J.J.A., Dicke, M., 1999. Electroantennogram responses of a predator, Perillus bioculatus, and its prey, Leptinotarsa decemlineata, to plant volatiles. Journal of Chemical Ecology 25, 2313-2325.

Wheeler, G.S., 2001. Host plant quality factors that influence the growth and development of Oxyops vitiosa, a biological control agent of Melaleuca quinquenervia. Biological Control 22, 256-264.

Wheeler, G.S., 2003. Minimal increase in larval and adult performance of the biological control agent Oxyops vitiosa when fed Melaleuca quinquenervia leaves of different nitrogen levels. Biological Control 26, 109-116.

Wheeler, G.S., Slansky Jr., F., Yu, S.J., 2001. Food consumption, utilization and detoxification enzyme activity of larvae of three polyphagous noctuid moth species when fed the botanical insecticide rotenone. Entomologia Experimentalis et Applicata 98, 225-239.

Wheeler, G.S., Massey, L.M., Southwell, I.A., 2003. Dietary influences on terpenoids sequestered by the biological control agent Oxyops vitiosa: effect of plant volatiles from different Melaleuca quinquenervia chemotypes and laboratory host species. Journal of Chemical Ecology 29, 188-207.

Wibe, A., Borg-Karlson, A.K., Norin, T., Mustaparta, H., 1997. Identification of plant volatiles activating single receptor neurons in the pine weevil (Hylobius abietis). Journal of Comparative Physiology A 180, $585-595$.

Wineriter, S.A., Buckingham, G.R., Frank, J.H., 2003. Host range of Boreioglycaspis melaleucae Moore (Hemiptera: Psyllidae), a potential biocontrol agent of Melaleuca quinquenervia (Cav.) S.T. Blake (Myrtaceae), under quarantine. Biological Control 27, 273-292.

Wink, M., 2003. Evolution of secondary metabolites from an ecological and molecular phylogenetic perspective. Phytochemistry 64, 3-19.

Zwölfer, H., Harris, P., 1971. Host specificity determination of insects for biological control of weeds. Annual Review of Entomology 16, 159-178. 